\title{
Review of tufa deposition and palaeohydrological conditions in the White Peak, Derbyshire, UK: implications for Quaternary landscape evolution.
}

\author{
Vanessa J. Banks ${ }^{1,2^{*}}$, Peter F. Jones ${ }^{2}$, David J. Lowe ${ }^{1}$, Jonathan R. Lee ${ }^{1}$, Jeremy Rushton ${ }^{1}$, and \\ Michael A. Ellis ${ }^{1}$. \\ ${ }^{1}$ British Geological Survey, Kingsley Dunham Centre, Nicker Hill, Keyworth, Nottingham NG12 5GG \\ ${ }^{2}$ University of Derby, Geographical, Earth and Environmental Sciences, Kedleston Road, Derby, DE22 1GB \\ * Corresponding author. E-mail address: vbanks@bgs.ac.uk
}

\begin{abstract}
.
This review considers the geological and geomorphological context of tufa barrages that occupy buried valley settings in the Wye catchment, Derbyshire. It describes the potential relationship of the tufa with locations of hypothesised river captures and inception horizon-guided groundwater flow paths. Tufa barrage development is associated with steps in the bedrock, which may be related to knick-point recession during river capture. Broad estimates of valley incision have been calculated from previously dated deposits. These support current interpretations of particularly significant effective base-level lowering during the Anglian and Devensian stages of the Quaternary and have the potential to add to the knowledge of regional uplift histories.
\end{abstract}

Key words: tufa, Quaternary hydrogeology, inception horizons, incision, landscape evolution.

\section{Introduction.}

Tufa is a terrestrial freshwater accumulation of calcium carbonate (Viles, 2004) that is commonly found in limestone terrain. Also referred to as travertine by some authors (Pentecost, 1999), it is precipitated when water that is saturated with calcium carbonate becomes supersaturated due to degassing of carbon dioxide. This can be caused by: atmospheric absorption of carbon dioxide, increase in temperature, decrease in pressure, physical agitation, aquatic plant photosynthesis (Lorah and Herman, 1988), or microbial processes (Pedley and Rogerson, 2010). In Britain, as in Central Europe, ${ }^{14} \mathrm{C}$-dating and pollen analysis have shown that a peak of tufa deposition occurred during the Atlantic and Sub-Boreal periods (5000-2500 BP) of the Holocene when climatic conditions were warmer and wetter (Goudie et al., 1993). The more recent decline in tufa formation has been attributed to a number of factors (Goudie et al., 1993; Pedley, 1993; Taylor et al., 1994) such as climate change, increased phosphates in the groundwater, deforestation and other anthropogenic impacts. Evidence that links tufa deposition with episodes of enhanced carbonate dissolution has the potential to answer important questions about the history of karstification and landscape evolution in limestone areas. The White Peak, Central England, UK (Figure 1) provides a useful test case for such an investigation.

Previous studies of tufa have concentrated largely on the implications for Holocene palaeoclimates and depositional environments, e.g. Andrews, 2006; Andrews et al., 1994, Andrews and Brasier, 2005 and Pedley, 1990. These studies rely on stable (oxygen and carbon) isotopes for environmental interpretations and uranium series dating for age determinations. Pedley $(1990,2009)$ presented a 
number of environmental framework models of tufa (Table 2), which were based on living and extinct systems in north-western Europe and the Mediterranean.

Figure 1: The White Peak, Derbyshire, showing the location, geological and hydrological setting of the research area.

This study considers what can be inferred about palaeohydrological processes and fluvial landscape evolution in the White Peak from the deposition, distribution and subsequent incision of tufa deposits. These aspects have hitherto been considered independently of each other. Whereas this study is focused on the Wye Valley catchment of the White Peak (Figure 2), it has implications for understanding tufa deposition, drainage development and landscape evolution in other karstic areas.

Figure 2. Tufa barrage localities (1, Wye Valley; 2, Coalpit Bridge; 3, Raper Lodge, and 4, Alport-byYoulgreave).

\section{Geological and Hydrogeological setting of the research area.}

2.1. Location and geomorphological context. Situated at the southern end of the Pennines, the dominant upland area of Central England, the White Peak comprises a major outcrop of Carboniferous (Dinantian) limestone up to $20 \mathrm{~km}$ in width and $30 \mathrm{~km}$ from north to south (Figure 1). It contrasts in character with the Dark Peak, which is underlain by Carboniferous (Namurian) sandstones and mudstones to the west, north and east (Figure 1). The limestone outcrop has the general form of a dissected plateau (Dalton et al. 1999) with a gently undulating surface at around 300 to $370 \mathrm{~m}$ OD and a complex network of deeply incised valleys (dales), which are mainly dry (Warwick, 1964). The Rivers Dove and Derwent respectively flow close to the western and eastern boundaries of the White Peak (Figure 1) and represent major tributaries of the River Trent to the south-east. The River Wye, referred to in the present study, is the largest tributary of the Derwent (Figure 1) and has a total catchment of approximately $271 \mathrm{~km}^{2}$.

2.2. Geology and occurrence of tufa. The Dinantian outcrop of the White Peak is surrounded by younger rocks that generally dip away from it and represents an extensive inlier commonly referred to as the Derbyshire Dome (Aitkenhead et al., 2002). The rock sequence that crops out in the Wye Valley (Table 1 ) is broadly younging to the east. This distribution of strata is interrupted to the east where younger deposits occupy structurally controlled intra-shelf basins, namely the Ashford Basin, which developed at the beginning of the Brigantian (Gutteridge, 1987 and 1989) and to the south, the subsequent Stanton Basin (Gutteridge, 1987).

Quaternary superficial deposits (Figure 3) are relatively scarce in the White Peak. Terrigenous clastic sediments predominantly include river alluvium, scree deposits, till and head. Aitkenhead et al. (1985) suggest that the paucity of till and other glacial deposits can be attributed to the Derbyshire Dome remaining largely ice free during the most recent (Devensian, Table 3) glaciation. The main evidence for this lies in the occurrence of screes in the limestone dales and laterally extensive loess deposits across the plateau surface (Catt, 1977; Piggott, 1962). An additional factor is the karstic 
nature of the bedrock, into which a considerable volume of a range of sediments has infiltrated, e.g. Shaw (1984). Many of the superficial deposits are associated with specific geomorphological settings (Figure 3) and are attributed to cold-climate processes operating during the Devensian (Aitkenhead et al., 2000). Sporadic patches of till present on the limestone outcrop are attributed to an earlier ice

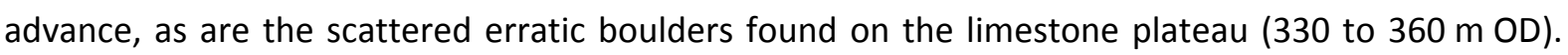
These are believed to be a legacy of the Mid Pleistocene Anglian glaciations.

Secondary deposits, characteristic of limestone terrains, including: tufa, speleothems and cements have been described (Burek, 1977; Ford et al., 1983, and Rowe et al., 1989). The principal tufa localities in the White Peak (Burek, 1977; Gunn, 1985) are restricted to the outcrop of the more karstified limestones, including the: Monsal Dale Limestone Formation; Miller's Dale Limestone Member of the Bee Low Limestone Formation, and the Eyam Limestone Formation, (Banks et al., 2009). Examples of the fluviatile (barrage model) and springline model have been described (Pedley, 1990, 1993; Pentecost, 1999; Taylor et al., 1994, and Table 2). The most extensive deposits in the Wye catchment are associated with the presence of buried valleys at NGR (National Grid Reference) NGR SK 216650 and NGR SK 170710 in the Lathkill and Wye valleys respectively (Pedley, 1993, Figure 2), which coincide with the points of river capture postulated by Johnson (1957, 1969, described below).The largest exposure can be seen at Alport-by-Youlgreave [NGR SK 22106467, Figure 2 and Figure 4]. Here the exposed tufa reaches a thickness of about $10 \mathrm{~m}$, but rests on buried deposits that extend below river level giving a total thickness of at least $20 \mathrm{~m}$. There is no active tufa deposition associated with this locality, which is referred to as the Old Alport tufa (Table 2, figures 4 and 5).

Table 1: Carboniferous bedrock geology of the White Peak, Central England (based on Waters et al., 2007).

Figure 3: Generalised south-west to north-east section (approximately $12 \mathrm{~km}$ ) across the White Peak to show superficial deposits (bedrock adapted from BGS 1: 50000 Sheets 111 and 99).

Figure 4: Old tufa exposed at Alport-by-Youlgreave.

Figure 5: Old Alport Tufa. (Note cyanobacterial matter, including moulds of sheaths).

The tufas of lower Lathkill Dale (Figure 2) have been classified in the barrage model (Pedley et al. 2000) and are associated with steps, of approximately $5 \mathrm{~m}$, in the valley floor. This scenario is typically represented by tufa at Raper Lodge [NGR SK 21496491, Figure 2] and Alport-by-Youlgreave [NGR SK 22106467; Towler, 1977; Figure 2] (Pedley, 1993 and Pedley et al., 2000). Extensive sills of tufa, observed in the Lower Lathkill, between NGR SK 21366527 and NGR SK 21456520 and between NGR SK 21466518 and NGR SK 21566492, associated with the tufas at Coalpit Bridge and Raper 
Lodge, appear to extend across the river and were identified by Pedley et al. (2000) as the positions of additional barrage locations. The water level in the barrage pool at Raper Lodge, Lathkill Dale [NGR SK 21383 65240] is artificially maintained 1 $\mathrm{m}$ above the barrage surface, but this is still the most natural active tufa barrage in England (Andrews et al., 1994, p350). At this location the tufa is soft and porous, having developed around vegetation (Figure 6).

Table 2: Tufa classification and occurrence (Framework Models based on Pedley, 1999 and 2009).

Figure 6: Tufa sill currently precipitating at Raper Lodge. (Note finer grains than those shown in Figure 5 and the granular appearance of much of the calcite and cyanobacteria sheaths.)

2.3. Hydrogeology and hydrology. The regional hydraulic gradient of the groundwater of the White Peak is towards the east (Downing et al., 1987). Current surface drainage of the White Peak is primarily via the River Wye, which is approximately $25 \mathrm{~km}$ in length. The River Lathkill, with its tributary the River Bradford, forms an easterly flowing tributary, of approximately $7 \mathrm{~km}$ (Figure 2). Whereas the River Wye is fed by both autogenic and allogenic springs in the Buxton area (Figure 1), the River Lathkill is largely an autogenic river, i.e. its source and entire length of flow lie almost totally within Dinantian limestones. Bubble Springs [NGR SK 20516611, Figure 7] form the upstream limit of perennial flow in the River Lathkill and the River Bradford is perennial downstream of Well Head Spring [NGR SK 20006325, Figure 7]. The confluence of the River Bradford with the River Lathkill, at NGR SK 22056449, in the village of Alport-by-Youlgreave (Figure 2), is associated with the extensive tufa deposits (Andrews et al., 1994) described above. Typical of limestone terrains, there is a significant groundwater (baseflow) contribution (possibly in the order of $68 \%, \mathrm{CEH}, 1999$ ) to the rivers Wye and Lathkill.

The limestone hydrogeology can be defined in terms of geological units of comparable hydrogeological properties (Banks et al., 2009). In this context, the Monsal Dale Limestone Formation, the Miller's Dale Limestone Member (of the Bee Low Limestone Formation) and the Eyam Limestone Formation (Table 1) have been grouped together as a single hydrogeological unit. This unit exhibits greater karstification, which is characterised by anastomosing conduit development along discrete planes (inception horizons) and by groundwater storage largely associated with faults and layers of weathered volcanic ash (clay wayboards; Walkden, 1974) that are inter-bedded with the limestones. All of the tufa deposits under consideration are associated with this unit. The inception horizons (Lowe, 2000) are bedding-parallel and comprise relatively thin zones within the limestone that exhibit a greater propensity for dissolutional permeability development as a consequence of geochemical processes in the limestone (Banks, 2007). Resulting from the laterally extensive development of anastomosing drainage, this unit hosts a greater number of lower discharge springs than is associated with other hydrogeological units in the Wye catchment in which permeability is more closely related to structural influences.

The karstic nature of the bedrock renders it difficult to establish the regional base-level of the limestone catchment. The surface water drainage flow paths and the evidence for a proportion of underflow (flow from the local to regional catchment scale, e.g. Töth, 1963) derived from water 
balance calculations, point to the River Trent (Banks, 2007, section 5.7) as the regional base-level. Consequently, it can be concluded that the development of the drainage of the area will have been influenced by the evolution of both the River Derwent and the River Trent. Knowledge of the evolution of the River Derwent extends only as far back as the Anglian (Oxygen Isotope Stage [OIS] 12) glaciation (Howard et al., 2007). A longer history has been established for the River Trent. Current research (Howard et al., 2007, White et al., 2010) points to a pre-Anglian outlet for the Trent system via a gap in the Jurassic escarpment at Ancaster to the Wash Basin, which was excavated by ice during the Anglian glaciation (White et al. 2010). Following deglaciation, drainage was reestablished to the Wash Basin via Lincoln (White et al., 2010). The modern course of the River Trent northwards to the Humber estuary has been attributed to diversion by ice during the Devensian glaciation (OIS 2; White et al., 2010). This suggests that significant changes to the hydraulic gradient of the White Peak occurred during the Mid to Late Pleistocene and that the present easterly hydraulic gradient evolved from a more south-easterly, pre-Anglian groundwater flow direction. Karst processes (limestone dissolution) fossilise early subsurface flow paths, such that cave exploration (e.g. Beck, 1980) and dye tracing (Gunn, 2004) offer the potential to provide invaluable information on the evolution of the palaeohydrogeology with additional information obtained from speleothem and sediment chronologies. Published speleothem and sediment dates, which are described below, point to a south-west to north-east unveiling of the limestone by erosion of the overlying Namurian strata from the early Pleistocene. A superficial comparison of the flow paths, as indicated by the caves on the west side of the River Derwent at Masson Hill, Matlock, indicates a north-west to south-east flow direction (Noel, 1987). However, those of the more northern catchments, with younger speleothem dates (Table 3), such as the Lathkill Head cave system with a flow path that closely mirrors that of the surface water course of the Upper Lathkill, suggest a more easterly gradient. Clearly, such an interpretation needs to consider the influence of any earlier phases of cave development (speleogenesis) and structural influences, thus a more thorough investigation would be required to draw firm conclusions from this line of evidence.

Johnson (1957 and 1969) recognised the significant influence of structure, as reflected in the former distribution of Namurian strata, on the surface expression of the streams. Similarly, observations with respect to structural influences (e.g. faults and joints) on the groundwater and distribution of springs have been made (Banks et al., 2009). These observations can be extended to consider structural influence on the interplay between ground- and surface water, which in turn offers the potential to assist in elucidating the hydrological evolution of the region. This is exemplified in upper Lathkill Dale, where the surface water course approximately overlies the course of the active Lathkill Cave system. Dissolution guided by structural elements is likely to have been further developed by the downward development of karst processes consequential to the injection of subglacial and fluvioglacial meltwaters into openings such as faults, joints and any pre-existing dolines, in the limestone. The relative absence of mature conduits (caves) beneath a stream, especially where it is following the dip of the strata, suggests discordant or subsequent stream development. This would appear to be the case for the River Lathkill downstream of Bubble Springs and the River Wye between Litton Mill and Ashford in the Water.

A network of dry valleys provides evidence of the palaeohydrological evolution of both the surface water and the groundwater drainage systems. The dry valleys exhibit the same form of dendritic pattern as is found on other rocks and this pattern can be seen to extend on to the Namurian strata (Figure 1). This suggests inheritance from a drainage network established on an impermeable cover, 
which has been interpreted as largely mudstones (Johnson, 1969; Warwick, 1964), or till. It should also be noted that prior to karstification the limestone was also effectively impermeable and also that further development of the dry valleys is likely to have occurred during periglacial conditions. Associated with the occurrence of dry valleys is the presence of blind valleys, where streams flowing off overlying impermeable strata sink into the limestones.

The easterly hydraulic gradient and the concept of inheritance have informed models of the early fluvial evolution of the White Peak, e.g. Linton $(1951,1956)$. Subsequent models also considered the geological influence and, using data related to terraces, Johnson (1957) postulated that the River Lathkill formerly comprised two rivers: an Upper Lathkill (Figure 7), established in the early Pleistocene and captured by the Lower Lathkill, due to north-westerly headward erosion across a former Namurian cover, and a Lower Lathkill. Prior to its capture by the Lower Lathkill, the Upper Lathkill flowed eastwards to the Derwent. At the time of river capture it is considered (Johnson, 1957) that river base-level was related to the level of the interface between Namurian sandstones and mudstones and that it would have been in the order of $100 \mathrm{~m}$ above the current day river level, flowing on the Namurian strata. Again considering geological influence on river capture processes, Johnson (1957) also suggested that the Gratton Dale Stream (Figure 7), a tributary of the River Bradford, cut back to capture the south-easterly flowing stream in Long Dale [NGR SK 20075963]. A capping of Namurian strata (Figure 1) appears to have guided the stream along the edge of the Stanton Basin.

Figure 7: Postulated river courses (adapted from Johnson, 1969). Key: Dashed lines indicate the postulated positions of the former (pre-Anglian) river courses.

Similar models have been presented for the evolution of the River Wye, e.g. Johnson (1957). Examination of British Geological Survey maps indicates that the Ashford intra-shelf basin (Figures 1 and 7) has exercised some guidance on the alignment of the River Wye, albeit that this might simply reflect the basinal constraints on facies distribution, with faulting juxtaposing sandstones and mudstones in the Namurian strata. Johnson (1957) favoured this view; in his interpretation, strikestreams that developed on the Namurian mudstones were subsequently superimposed on the limestone, thereby giving rise to the seemingly incongruous meander at Monsal Head (Figure 7). Johnson (1969) suggested that the pre-glacial drainage might have comprised a Wye and a Lower Wye trending north-west to south-east, having had sufficient time after superimposition to develop concordance with the structure of the limestone. He considered that the Lower Wye inherited the Monsal Head meander from the Namurian cover and captured the Wye headwaters by headward erosion and that the Rymas Brook is a consequent stream that possibly represents the beheaded Upper Wye. The occurrence of significant tufa deposits associated with karstification of the limestone in the lower Wye and lower Lathkill in buried valleys suggests that river incision was rapid.

\section{Karst processes and dating.}

Understanding the dissolutional processes operating in the karst environment is essential to establishing the source of the carbonate that forms the tufa. In unconfined karst settings, dissolution is dominated by carbonic acid reactions fed by carbon dioxide primarily derived from a range of biogenic processes (Atkinson, 1977). During conduit gestation, initial openings are slowly enlarged 
by groundwater that is close to saturation with respect to calcium carbonate. The routes conducting the highest discharge are subject to greater dissolution (Palmer, 2002). As discharge is increased with hydraulic gradient conduit initiation is commonly attributed to uplift (Palmer, 2002), but could also be initiated by rapid downcutting and the lowering of base-level, or to the high head imposed by subglacial meltwater. During periods of flooding, flow rates are relatively higher and water is relatively aggressive, with lower $\mathrm{pH}$ and lower initial concentrations of calcium. Furthermore, additional flow paths are activated, in both the vadose and the phreatic zones, facilitating rapid dissolution and increasing the efficiency of the drainage system. The inverse relationship between calcium carbonate solubility and temperature means that cooling of groundwater can increase its aggressiveness. Thus, an understanding of the influence of glacial and periglacial conditions is all the more important. Variations in the saturation state with respect to calcium carbonate can result when two solutions, each saturated with respect to calcium carbonate, but in equilibrium with different carbon dioxide vapour phases, are mixed (mixing corrosion, Bögli, 1964). Supersaturation with respect to calcium carbonate is critical, as is the potential for significant outgassing of carbon dioxide to overcome the kinetic resistance to calcium carbonate precipitation (Lorah and Herman, 1988). This may occur as a consequence of physical water agitation (Chen et al., 2004; Lorah and Herman, 1988; Vázquez-Urbez et al. 2010), or biological uptake of carbon dioxide (Pentecost, 1999). Irrespective of the degassing process, biological mediation in the form of microparticulate trapping is significant in binding the sediment and providing a substrate for growth, as illustrated in Figure 6.

Other than during the Anglian stage (OIS 12), when hydrostatic pressures associated with any subglacial meltwater would have been particularly erosive and are associated with buried channel formation (e.g. White et al., 2010), the highest energy phases of the karst rivers were during periods of deglaciation. Cold meltwater would have been chemically and physically aggressive to the limestone, albeit that surface armouring by glacial materials, including remnants of till that were subsequently washed into karst conduits, might have limited dissolutional activity. This is comparable with Bridgland's (2000) model of Mid and Late Pleistocene terrace aggregation and valley erosion synchronized with glacial-interglacial cycles, with aggradation associated with ameliorating climatic conditions. The remoteness of the Wye catchment from the coast and from the River Trent suggests that climatic forcing, moderated by local uplift and gradients, was responsible for the valley incision (Bridgland, 2000; Maddy, 1996; Rose, 2010 and Westaway 2009). It is reasonable to assume that once the limestone had been unroofed of its former Namurian cover, the stream would have functioned much as it does now, except when the hydrology was dominated by distally-derived glacial or periglacial meltwater.

The Old Alport Tufa (Alport-by-Youlgreave) has been dated to the Ipswichian (OIS 5e) (Pedley et al., 2000; Table 3). Significantly, the top of this deposit at Alport-by-Youlgreave (150 m OD) coincides with the level of a dominant inception horizon in Lathkill Dale, which lies close to the boundary between the Eyam Limestone and the overlying Widmerpool Formation (Table 1). Similarly, the top of the old tufa at Raper Lodge lies close to the level of another dominant inception horizon. It is plausible that, activated by rapid downcutting, gestation along the inception horizons has provided the source of the calcium carbonate for tufa precipitation, such that the position of the barriers in the lower Lathkill and lower Wye valleys represent zones of calcium carbonate-saturated groundwater resurgence and that degassing of carbon dioxide as a consequence of physical turbulence and biological mediation facilitated initial tufa development at the barrier sites (Figure 8). The ongoing deposition of the sill deposits can be attributed to carbonate precipitation as a 
consequence of vadose zone recharge (water that is saturated with calcium carbonate and biogenically enriched in carbon dioxide) mixing with surface (stream) water at atmospheric concentrations of carbon dioxide. Currently springs in the Monsal Dale Limestone Formation have been shown to be saturated, or close to saturation with calcium carbonate and closed to carbon dioxide with calculated partial pressures of carbon dioxide in the order of $1.2 \times 10^{-3} \mathrm{~atm}$ (Banks et al., 2009). At this concentration relatively small decreases in carbon dioxide are associated with significant reductions in calcium carbonate solubility, which facilitates carbonate precipitation. The closed nature of the springs has been attributed to the form of the flow paths, which comprises bedding-guided inception horizons.

Further evidence for a groundwater component to tufa precipitation comes from the occurrence of groundwater-associated ostracods in borehole core samples obtained from Alport (Taylor et al., 1994). Additionally, Pedley et al., (2000) noted that in the vicinity of Coalpit Bridge (NGR SK 21455 65189), immediately to the south of the ongoing tufa deposition at Raper Lodge (Figure 8), part of the principal barrage at Raper Lodge lies on an eroded limestone bench. At this location the bedding dips steeply, associated with a cross-valley fault. This indicates that the pre-tufa incised valley was predisposed to developing a step-like profile and that the principal barrages initially developed in the vicinity of steps in the profile. Where the steps are associated with faults, there is a strong possibility of spring resurgences, as exemplified at Bubble Springs, where inception horizonguided groundwater resurges from a depth of approximately $30 \mathrm{~m}$ (Banks, 2007).

Holocene tufa accumulation rates behind the barriers were calculated to be in the order of $2.5 \mathrm{~mm} /$ year (Andrews et al., 1994). The rates were calculated from preliminary dating of cores taken from the barrier lake deposits that formed immediately downstream of the barrages, and oxygen isotopes have been used to suggest that air temperatures were in the order of $2^{\circ} \mathrm{C}$ higher during the period of tufa deposition (Andrews et al., 1994). Pedley (1993) and Pedley et al., (2000) established that there is up to $16 \mathrm{~m}$ of channel fill in the area of the former lake associated with the tufa development. The channel fill deposits comprise organic micrite and peat, micrite, clay and soil (Pedley, 1993). Data on the Wye valley tufas are not as detailed as for the Lathkill ones. Barrages in the Wye valley were formed on limestone ridges, suspected to have been formed by a meandering watercourse (Pedley, 1993) guided by the resistance of the basaltic bedrock. Sediments comparable with those in the Lathkill valley were recorded. The sediments are up to $10 \mathrm{~m}$ in thickness in the vicinity of Monsal Head. The key differences to the tufas in the Lathkill valley are: the absence of pre-Holocene tufas; the absence of ongoing deposition, and the more pronounced degradation of the Wye tufas.

Figure 8: Geomorphological sketch to show the relationship of tufa with the valley system in Lower Lathkill Dale.

Age data (Table 3; Andrews et al., 1994 and Taylor et al., 1994) determined from tufa samples obtained from the lower Lathkill Dale barrage (Alport-by-Youlgreave) and the barrage lake deposits (Raper Lodge) have been used, in conjunction with speleothem dating, to contribute to the improved understanding of the Quaternary stratigraphy (Table 3). However, as emphasised by Ford (1999), many cave deposits await the application of modern dating techniques. More specifically, speleothem dating (Ford et al., 1983) was largely carried out using alpha counting analysis to 
determine ${ }^{230}$ Uranium/ $/{ }^{234}$ Thorium. This technique has been superseded by mass spectrometry, which generates more reliable results from smaller samples, as well as giving greater precision. Consequently, greater refinement of the dating of the stages and sub stages is now possible; suggesting the potential for future updating of the Quaternary stratigraphy of the White Peak, particularly in relation to the recognition, identification and dating of glacial episodes.

\section{Landscape erosion in the Wye and Lathkill valleys.}

Detailed recording of the tufa deposits in lower Lathkill Dale (Andrews et al. 1994; Pedley, 1993, Pedley et al., 2000, and Taylor et al., 1994) has provided evidence of erosional events that further elucidate the Quaternary landscape evolution of the eastern side of the White Peak (Table 3). Areas of tufa deposition in the Wye and Lathkill valleys coincide with buried valleys and points of river capture that were identified by Johnson (1957) and are indicative of periods of incision followed by (tufa) deposition. Like the tributaries of the Wye upstream of Monsal Head, The Lower Wye and the Lower Lathkill are considered to be subsequent streams (Johnson, 1957) that postdate the earlier consequent, south-easterly flowing Upper Wye and Upper Lathkill. Preservation of the topography in these features is indicative of recent downcutting, but the dating of incision is more speculative than that of the deposition of the tufa deposits (Table 3). Evidence from the work in the Lathkill valley (Pedley et al., 2000) indicates that incision occurred as a consequence of: i) glacial erosion (glacier and/ or glacial meltwater erosion), ii) hydrologically-driven erosion associated with a change in hydraulic conditions (including relative uplift), or iii) headward retreat and river capture of the Upper Lathkill by the Lower Lathkill. These options are considered further below.

The alignment of glacial striae on bedrock surfaces and the provenance of glacial erratics indicate that south-easterly flowing Anglian ice, derived from the north-west (Pennines, Cumbria and Western Scotland) spilled into this area via a col at Dove Holes (Johnson, 1967, Figure 1). The scarcity of till deposits cannot be relied upon as evidence for a limited distribution of glacier ice. This is because preserved outcrops of till are closely associated with the distribution of remnant mudstone (Straw and Lewis, 1962), which prevented sediment from being washed into voids in the underlying limestone. Where the limestone was exposed there was a greater likelihood of net erosion of better drained areas of the limestone. Probably the entire area was ice covered during the Anglian glacial maximum (Aitkenhead et al., 2002). The coincidence of the buried valleys with the postulated direction of ice movement, suggests that they could be subglacial valleys, a view supported by Burek (1977). Pedley et al. (2000, p. 732) provided supporting evidence of glacial influence, suggesting that "a basal lithoclast breccia in clay matrix" might be soliflucted till. Straw (1968) presented a view that the capture of the Upper Wye by the Lower Wye was attributable to the presence of ice in the Derwent valley impeding the easterly course of the Upper Wye. It is not easy to attribute this process to both the Wye and the Lathkill with one outlet (Lower Wye) being maintained whilst the Upper Lathkill was blocked. With respect to alternative hypotheses for river capture, it is plausible that a lowering of base-level would steepen hydraulic gradients and facilitate the development of south-easterly flow paths, which are more concordant with the structure and basement dip. However, this would not account for the relatively straight stretches of the River Wye [between NGR SK17359 73418 and NGR SK18309 71665] and River Lathkill between [NGR SK21023 65930 and NGR SK21375 65227], which cross the geological structure. A process of headward retreat and river capture, as was hypothesised by Johnson (1969) and Warwick (1976), can also be linked to glacial erosion. Both capture zones lie close to the western margin of the Namurian outcrop and breaching 
of the mudstone cover followed by active dissolution of the underlying limestone might have facilitated capture. Knick-point migration associated with tufa accretion has been described in other catchments with tufa accumulations of comparable ages (Carlson, 1998) and is implicit in the remnant bedrock step at the location of the Raper Lodge tufa dam. Accordingly, it seems reasonable to attribute valley incision to the period of the Anglian glaciation (OIS 12) or earlier. Equally, it seems likely that the capture of the Upper Lathkill by the Lower Lathkill and of the Upper Wye by the Lower Wye was coincident with the unroofing of these areas of limestone by removal of overlying Namurian strata.

The valley of the River Bradford is closely related to the outcrop of the Namurian strata in the Stanton Basin, which is indicative of more recent incision than that of either the upper or lower Lathkill. Recent interpretations of the Quaternary history of the Peak District (Aitkenhead et al., 2002) and the incision of the valley into the southern edge of the Ipswichian (OIS 5e) tufa suggest that the downcutting occurred during the Devensian. This provides supporting evidence for Johnson's (1957) notion of Gratton Dale cutting back to capture the stream in Long Dale, which would have occurred as Long Dale gradually dried up in response to base-level lowering.

The buried valleys in both the Wye and the Lathkill are unrelated to the dip of the limestone, such that the regional hydraulic gradient is locally reversed. This is evident in Lathkill Dale where tufa deposition has occurred and continues on both sides of the valley. The local reversal of the hydraulic gradient is facilitated by the low angles of dip of the limestones in this area.

Known ages of downcutting have been used to calculate mean maximum rates of incision at the downstream end of the catchment (Table 4), assuming a model comparable with that of Maddy (1997). The calculated rates suggest significant downcutting during the Anglian (representing the cold to warming erosive stage of Bridgland, 2000) with background uplift rates of 1.5 to $4.0 \mathrm{~cm} / \mathrm{ka}$, which is lower than the Early to Mid Pleistocene uplift rate of 7 to $10 \mathrm{~cm} / \mathrm{ka}$ that was calculated by Maddy et al. (2000) for southern catchments, but comparable with the Early to Mid Pleistocene incision rates $(4.12 \mathrm{~cm} / \mathrm{ka}$ ) calculated by Rowe et al. (1989) for the Manifold catchment. Consideration has also been given to the gradient of the incised valley floor, as indicated by the elevations of rockhead determined using geophysics (Pedley et al., 2000). A gradient of 1:126 has been determined between Coalpit Bridge and the confluence with the River Bradford. This is a relatively gentle gradient when compared with that of Cressbrook Dale (a possible spillway channel at NGR SK 1731 7343, Figure 1), where a gradient of 1:57 has been determined from the thalweg plot. 
Table 3: Quaternary stratigraphy and landscape evolution represented by speleothem dating and tufa barrage development in White Peak. 1. Aitkenhead et al., 2002. 2. Ford et al. 1983. 3. Rowe et al., 1989.

Table 4: Mean maximum rate of relative downcutting in the Lathkill catchment.

\section{Conclusions and implications for the Quaternary evolution of the White Peak.}

This review and its analysis and interpretation bring new insights to the processes associated with tufa deposition in the White Peak and provide supporting data regarding rates of Quaternary uplift and landscape evolution in the area. The following issues have been identified:

1. There was a likely south-west to north-east unroofing of the limestone in the White Peak. Whilst there is limited evidence of vadose incision of conduits and caves, gestation of permeability along inception horizons and valley incision could be related either to Quaternary uplift, or falls in base-level, or a combination of the two. The distance of the catchment from the coast suggests that climatic forcing, moderated by uplift, is responsible for valley incision. The evidence points to relatively recent unroofing of the eastern side of the White Peak. This helps to explain the lower topographical contrast between the limestones and the surrounding Namurian siliciclastic rocks than might be anticipated if continuous dissolution and consequential lowering of limestone left siliciclastic rocks as ridges surrounding the limestone, as is characteristic of more mature karst landscapes (Simms, 2004).

2. The straight form of the associated river stretches and existence of buried valleys that cross the geological structure indicate that river capture of the Upper Wye by the Lower Wye and of the Upper Lathkill by the Lower Lathkill occurred as a consequence of Anglian (or earlier) subglacial erosion and knick-point recession, associated with the stripping of Namurian strata from the eastern side of the White Peak.

3. The widening of immature voids was facilitated by topographic unloading associated with removal of Namurian strata exposing the limestones to an initial phase of dissolution by subglacial meltwaters, followed by the subsequent stress relief associated with glacial unloading and development of vadose zone flow paths enhanced by biogenically enriched recharge during the interstadials. 
4. Streams cutting down through inception horizons influenced local hydraulic gradients. This process, in turn, influenced the location and amount of dissolutional enlargement along inception horizons.

5. Field observations suggest that the tufa barrage deposits within the Wye catchment are largely related to dominant inception horizons in the Monsal Dale and Eyam Limestone formations.

6. Tufa barrages were established in the areas identified by Johnson (1957) as zones of river capture and are associated with faults and associated steps in the bedrock. This may be attributable either to the guidance of bedrock erosion by specific beds in the limestone, or to a locally increased expression of regional uplift.

7. The published dates of known tufa barrages in the Wye catchment demonstrate that there were two main phases of tufa formation (Pedley et al. 2000, Taylor et al., 1994). These have allowed broad conclusions to be drawn with respect to the hydrological evolution of the Lower Lathkill and rates of fluvial incision on the eastern side of the White Peak (Table 4).

8. The geometric relations of the erosional and depositional features have been used to inform estimates of incision rates that appear to support current interpretations of more significant erosion during the Anglian and the Devensian (16 to $36 \mathrm{~cm} / \mathrm{ka}$; Table 4), superimposed on relatively low rates of uplift ( 1.5 to $4.0 \mathrm{~cm} / \mathrm{ka}$ ).

9. The review has identified some potential research directions to test the hypotheses that have been presented. In particular: the linking of the tufas to enhanced dissolution of calcium carbonate along inception horizons awaits a detailed study of the stable isotopes; the use of stable isotopes to confirm the palaeoclimatic conditions at the time of deposition; linking of karst processes with the evolution of the rivers Trent and Derwent; modern dating of the speleothem deposits of the White Peak, which may further elucidate understanding with respect to the prevailing conditions during the Wolstonian stage, and more extensive investigation of the processes involved in the formation of the buried valleys.

10. The linking of periods of flow path gestation (as a consequence of landscape incision) with tufa deposition reaffirms that carbonate availability is as important as the climatic conditions and processes associated with carbon dioxide outgassing in tufa deposition. This is exemplified at different scales in a range of karst environments where there has been rapid effective incision, e.g. Glover and Robertson (2003), Schäfer et al. (2007), Smith, J.R. et al. (2004) and Torres et al. (2005).

\section{Acknowledgements.}

Figures 1, 2, 3, 7 and 8 have been significantly improved by Henry Holbrook, Carto GIS, British Geological Survey. The paper has been much improved as a consequence of the review process and our thanks are extended to Dr Steve Booth and Dr Peter Rowe. V.J. Banks, D.J Lowe, J.R. Lee, J. Rushton and M.A. Ellis publish with the permission of the Executive Director of the British Geological Survey (NERC). Vanessa Banks gratefully acknowledges a bursary granted by the University of Huddersfield and managed by Prof J Gunn (University of Birmingham).

\section{References:}


Aitkenhead, N., Barclay, W.J., Brandon, A., Chadwick, R.A., Chisholm, J.I., Cooper, A.H. and Johnson, E.W. 2002. British Regional Geology: The Pennines and adjacent areas (Fourth edition). British Geological Survey, Keyworth. 206pp.

Aitkenhead, N., Chisholm, J.I. and Stevenson, I.P. 1985. Geology of the country around Buxton, Leek and Bakewell. British Geological Survey. HMSO. 168pp.

Andrews, J.E. 2006. Palaeoclimatic records from stable isotopes in riverine tufas: Synthesis and review. Earth-Science Reviews 75, 85-104.

Andrews, J.E. and Brasier, A.T. 2005. Seasonal records of climatic change in annually laminated tufas: short review and future prospects. Journal of Quaternary Science, 20 (5), 411-421.

Andrews, J.E., Pedley, H.M. and Dennis, P.F. 1994. Stable isotope record of palaeoclimatic change in a British Holocene tufa. The Holocene, 4, 349-355.

Atkinson, T.C. 1977. Carbon dioxide in the atmosphere of the unsaturated zone: an important control of groundwater hardness in limestones. Journal of Hydrology, 35, 111-123.

Banks, V.J. 2007. Karst hydrogeology of the southern catchment of the River Wye, Derbyshire. Unpublished PhD thesis. University of Huddersfield. 345pp.

Banks, V.J., Gunn, J. and Lowe, D.J. 2009. Stratigraphical influences on the limestone hydrogeology of the Wye catchment, Derbyshire. Quarterly Journal of Engineering Geology and Hydrogeology, 42, 211-225.

Beck, J.S. 1980. Aspects of speleogenesis in the Carboniferous Limestone of North Derbyshire. Unpublished PhD. Thesis. University of Leicester. 336pp.

Bögli, A., 1964. Mischungskorrosion: Ein Beitrag zur Verkarstungsproblem: Erdkunde, 18, 83-92.

Bridgland, D.R. 2000. River terrace systems in north-west Europe: an archive of environmental change, uplift and early human occupation. Quaternary Science Reviews 19, 1293-1303.

British Geological Survey. 1978. 1: 50000 Series Sheet 111 Buxton (Solid and Drift). BGS, Natural Environment Research Council.

British Geological Survey. 1977. 1: 50000 Series Sheet 99 Chapel en le Frith (Solid and Drift). BGS, Natural Environment Research Council.

Burek, C.V. 1977. The Pleistocene Ice Age and after. In: Limestones and Caves of the Peak District. Ed. Ford, T. D. pp. 87-128.

Burek, C.V. 1978. Quaternary deposits on the Carboniferous Limestone of Derbyshire. Unpublished Ph. D. thesis, University of Leicester.

Burek, C.V. 1991. Quaternary history and glacial deposits of the Peak District. In: Glacial Deposits in Gt. Britain and Ireland. Ed. Ehlers, J., Gibbard, P.L. and Rose, J. pp. 193-201. 
Carlson, M.L. 1998. Knickpoint migration and tufa accretion in five South River tributaries, Central Virginia. Eleventh Keck Research Symposium in Geology Proceedings: Amherst College, Amherst, MA.

Catt, J.A. 1977. Loess and Coversands. In: Shotton, F.W. (Editor), 1977. British Quaternary Studies Recent Advances. Clarendon Press, Oxford, 221-230.

Centre for Ecology and Hydrology (CEH), 1999. Flood Estimation Handbook CD-ROM.

Chen, J., Zhang, D.D., Wang, S., Xiao, T. and Huang, R. 2004. Factors controlling tufa deposition in natural waters at waterfall sites. Sedimentary Geology, 166, 353-366.

Clayton, K.M. 1979. The Midlands and Southern Pennines. In: Straw, A. \& Clayton, K.M. Eastern and Central England. London: Methuen.

Dalton, R., Fox, H. and Jones, P.F. 1999. Classic Landforms of the White Peak. Geographical Association and British Geomorphological Research Group. 51pp.

Downing, R.A., Edmunds, W.M and Gale, I.N. 1987. Regional groundwater flow in sedimentary basins in the U.K. In: Goff, J.C. and Williams, B.P.J (Eds.) Fluid Flow in Sedimentary Basins and Aquifers. Geological Society of London Special Publication 34. pp. 105-125.

Ford, T.D. 1999. The growth of geological knowledge in the Peak District. Mercian Geologist. 14, part 4, 161-145.

Ford, T.D., Gascoyne, M. and Beck, J.S. 1983. Speleothem dates and Pleistocene Chronology in the Peak District of Derbyshire. Cave Science, 10, No. 2, 103-115.

Glover, C. and Robertson, A.H.F. 2003. Origin of tufa (cool-water carbonate) and related terraces in the Antalya area, SW Turkey. Geological Journal, 38, 329-358.

Goudie, A.S., Viles, H.A. and Pentecost, A. 1993. The late-Holocene tufa decline in Europe. The Holocene, 3, 181-186.

Gunn, J. 1985. Pennine karst areas and their Quaternary history. In: Johnson, R.H. (ed). The geomorphology of North-west England. Manchester University Press.

Gunn, J. 2004. Dye tracing. In: Goudie, A.S. (Editor) Encyclopedia of Geomorphology. Routledge, London, UK, pp. 304-305.

Gutteridge, P. 1987. Dinantian sedimentation and the basement structure of the Derbyshire Dome. Geological Journal. 22, 25-41.

Gutteridge, P. 1989. Controls on carbonate sedimentation in a Brigantian intrashelf basin (Derbyshire). In Arthurton, R.S., Gutteridge, P. and Nolan, S.C. Eds. The role of Tectonics in Devonian and Carboniferous sedimentation in the British Isles. Yorkshire Geological Society Occasional Publication, 6, 171-187.

Howard, A.J., Bridgland, D., Knight, D., McNabb, J., Rose, J., Schreve, D., Westaway, R., White, M.J. and White, T.S. 2007. The British Pleistocene fluvial archive: East Midlands drainage evolution and 
human occupation in the context of the British and NW European record. Quaternary Science Reviews, 26, 2724-2737.

Johnson, R.H. 1957. An examination of the drainage pattern of the eastern part of the Peak District of North Derbyshire. Geog. Studies, 4, 46-55.

Johnson, R. H. 1967. Some glacial, periglacial and karstic landforms in the Sparrowpit-Dove Holes area of North Derbyshire. East Midland Geographer, 4, 224-238.

Johnson, R.H. 1969. The Derwent-Wye confluence re-examined. East Midland Geographer, 4, 421426.

Linton, D.L. 1951. Midland Drainage: some considerations bearing on its origin. Advancement of Science, 7, 449-456.

Linton, D. 1956. Geomorphology of the Sheffield region in: Sheffield and its region: a scientific and historical survey. British Association. (Sheffield), 24-43.

Lorah, M.M. and Herman, J.S. 1988. Chemical evolution of a Travertine Depositing Stream. Water Resources Research, 24, No.9, 1541-1552.

Lowe, D.J. 2000. Role of stratigraphic elements in speleogenesis: the speleoinception concept. In: Speleogenesis Evolution of Karst Aquifers. Eds. Klimchouk, A.B., Ford, D.C., Palmer, A.N. and Dreybrodt, W. pp. 65-76.

Maddy, D. 1997. Uplift-driven valley incision and river terrace formation in southern England. Journal of Quaternary Science, 12, 539-545.

Maddy, D. Bridgland, D.R. and Green, C.P. 2000. Crustal uplift in Southern England: evidence from the river terrace records. Geomorphology 33, 3-4, 167-181.

McMillan, A.A., Hamlin, R.J.O. and Merritt, J.W. 2005. An overview of the lithostratigraphical framework for the Quaternary and Neogene deposits of Great Britain (onshore). British Geological Survey Research Report RR/04/04 38PP.

Noel, M. 1987. The magnetostratigraphy of cave sediments in Masson Hill, Derbyshire. Proceeding of the Yorkshire Geological Society, 46, 3, 193-201.

Palmer, A.N. 1991. Origin and morphology of caves. Geological Society of America Bulletin, 103, 121.

Palmer, A.N. 2002. Speleogenesis in carbonate rocks. In: Gabrovsek, F.(Editor), 2002. Evolution of Karst: From Prekarst to Cessation. Postojna. pp. 43-59.

Pedley, H.M. 1990. Classification and environmental models of cool freshwater tufas. Sedimentary Geology, 68, 143-154.

Pedley, H.M. 1993. Sedimentology of the late Quaternary barrage tufas in the Wye and Lathkill valleys, north Derbyshire. Proceedings of the Yorkshire Geological Society, 49, part 3, 197-206. 
Pedley, M. H. 2009. Tufas and travertines of the Mediterranean region: a testing ground for freshwater carbonate concepts and developments. Sedimentology, 56, 221-246.

Pedley, H.M. and Rogerson, M. 2010. Introduction to tufas and speleothems. In: Pedley, H.M. and Rogerson, M. (Editors) 2010. Tufas and Speleothems: Unravelling the Microbial and Physical Controls. Geological Society of London Special Publication 336, 1 -

Pedley, H.M., Hill, I., Denton, P. and Brassington, J. 2000. Three-dimensional modelling of a Holocene tufa system in the Lathkill Valley, north Derbyshire, using ground-penetrating radar. Sedimentology, 47, $721-737$.

Pentecost, A. 1999. The origin and development of the travertines and associated thermal waters at Matlock Bath, Derbyshire. Proceedings of the Geologists' Association, 110, 217-232.

Pigott, C.D. 1962. Soil Formation and Development on the Carboniferous Limestone of Derbyshire. I Parent Material. The Journal of Ecology, 50, No.1, 145-156.

Rose, J. 2010. The Quaternary of the British Isles: factors forcing environmental change. Journal of Quaternary Science, 25, 399-418.

Rowe, P., Austin, T. and Atkinson, T. 1989. The Quaternary evolution of the South Pennines. Cave Science, 16, No. 3, 117-121.

Schäfer, D., Heinrich, W., Böhme, G. and Steiner, W. 2007. Aspects of the geology, palaeontology and archaeology of the travertine site of Weimar-Ehringsdorf (Thuringia, Central Germany). Cour. Forsch.-Inst. Senckenberg, 259, 141-147.

Shaw, R.P. 1984. Karstic sediments, residual and alluvial ore deposits of the Peak District of Derbyshire. Unpublished Ph. D. thesis, University of Leicester.

Simms, M.J. 2004. Tortoises and hares: dissolution, erosion, isostasy in landscape evolution. Earth Surface Processes and Landforms, 29, Issue 4, 477-494.

Smith, J.R., Giegengack, R. and Schwarcz, H.P. 2004. Constraints on Pleistocene pluvial climates through stable-isotope analysis of fossil-spring tufas and associated gastropods, Kharga Oasis, Egypt. Palaeogeography, Palaeoclimatology, Palaeoecology, 206, 157-175.

Straw, A. 1968. A Pleistocene diversion of drainage in northern Derbyshire. East Midland Geographer, 4, 275-280.

Straw, A. and Lewis, G.M. 1962. Glacial Drift in the area around Bakewell, Derbyshire. East Midland Geographer, 18 No.2, 72-80.

Taylor, D.M., Griffiths, H.I., Pedley, H.M. and Prince, I. 1994. Radiocarbon-dated Holocene pollen and ostracod sequences from barrage tufa-dammed fluvial systems in the White Peak, Derbyshire, U.K. The Holocene, 4, No.4, 356-364.

Tinkler, K.J. 2004, Knickpoint. In: Goudie, A.S. (Editor). Encyclopedia of Geomorphology Volume 2 (JZ), 595-596. 
Torres, T., Ortiz, J.E., Garcia de la Morena, M.A., Llamas, F.J. and Goodfriend, G. 2005. Ostracodebased aminostratigraphy and aminochronology of a tufa system in central Spain. Quaternary International, 135, 21-33.

Tóth, J. 1963. A theoretical analysis of groundwater flow in small drainage basins. Journal of Geophysical Research, 68, No.16, 4795-4812.

Towler, P.A. 1977. A geological survey and an investigation into the deposition and relationship with the present environment, of the tufa formation in Lathkilldale, Derbyshire. Unpublished B.Sc. Dissertation, University of Bristol.

Vázquez-Urbez, M., Arenas, C., Sancho, C., Osácar, C., Auqué, L. and Pardo, G. 2010. Factors controlling present-day tufa dynamics in the Monasterio de Piedra Natural Park (Iberian Range, Spain): depositional environmental settings, sedimentation rates and hydrochemistry. International Journal of Earth Sciences, 99, 1027-1049.

Viles, H.A. 2004, Tufa and travertine. In: Goudie, A.S. (Editor). Encyclopedia of Geomorphology Volume 2 (J-Z), 595-596.

Walkden, G.M. 1974. Palaeokarstic surfaces in Upper Visean (Carboniferous) limestones of the Derbyshire block, England. Journal of Sedimentary Petrology, 44, No. 4, 1232-1247.

Warwick, G.T. 1962. The characteristics and development of limestone regions in the British Isles with special reference to England and Wales. Actes de $2^{\text {me }}$ Congres Int. de Spel. (Bari-Lecce-Salerno, 1958), 1, 79-105.

Warwick, G.T. 1964. Dry valleys of the southern Pennines. Erdkunde, Bd. 18, 116-123.

Warwick, G.T. 1976. Geomorphology and Caves. In: Science of Speleology. Eds. Ford, T.D. and Cullingford, C.H.D. Academic Press, London. pp. 61-125.

Waters, C.N., Browne, M.A.E., Dean, M.T. and Powell, J.H. 2007. Lithostratigraphical framework for Carboniferous successions of Southern Great Britain (Onshore). British Geological Survey Research Report. RR/07/01. 70pp.

Westaway, R. 2009. Quaternary uplift of Northern England. Global and Planetary Change, 68, 357382.

White, T.S., Bridgland, D.R., Westaway, R., Howard, A.J. and White, M.J. 2010. Evidence from the Trent terrace archive, Lincolnshire, UK, for lowland glaciation of Britain during the Middle and Late Pleistocene. Proceedings of the Geologists' Association, 121, 141-153. 